\title{
NOTA POKOJOWA PAŃSTW CENTRALNYCH Z GRUDNIA 1916 R. I ODPOWIEDŹ ENTENTY W OPINIACH ÓWCZESNEJ PRASY KRAKOWSKIEJ
}

DOI: $10.15290 /$ sp.2020.28.04

\begin{abstract}
Abstrakt. W artykule omówione zostały komentarze głównych krakowskich dzienników („Czasu”, ,Głosu Narodu”, „Naprzodu” i „Nowej Reformy”) na temat noty pokojowej Państw Centralnych z grudnia 1916 r., jak również nieprzychylnej reakcji Ententy na tę ofertę. Przeprowadzona analiza pozwoliła uwypuklić istotne kwestie, zwłaszcza wynikające z cenzuralnych uwarunkowań i orientacji politycznej, ukazać różnice w postrzeganiu działań Ententy, omówić odniesienia do problemu odpowiedzialności za wybuch i przedłużanie wojny, czy też ustosunkowanie się do koncepcji lansowanych na łamach prasy zagranicznej.
\end{abstract}

Słowa kluczowe: I wojna światowa, nota pokojowa, mediacja, Ententa, Państwa Centralne, krakowskie dzienniki

\begin{abstract}
The article discusses comments from top Krakow daily newspapers ("Czas", "Głos Narodu", "Naprzód" and "Nowa Reforma") on the peace note of the Central Powers from December 1916, as well as the Entente's unfavourable response to the note. The article analyses the press' varying opinions on Entente's course of action, discusses the subject of blame for starting and prolongation of the Great War, as well as reactions to notions published in the foreign press.
\end{abstract}

Key words: World War I, peace note, Entente, Central Powers, Krakow daily newspapers

Celem artykułu jest omówienie opinii najważniejszych krakowskich dzienników zarówno na temat noty pokojowej Państw Centralnych z 12 grudnia 1916 r., jak i odpowiedzi Czwórporozumienia przekazanej kilkanaście dni później. Autor przyjął założenie, że przeprowadzona analiza pozwoli uwypuklić wynikające $\mathrm{z}$ orientacji politycznej czasopism różnice $\mathrm{w}$ postrzeganiu działań Ententy, omówić odniesienia do problemu odpowiedzialności za wybuch i przedłużanie wojny, czy też ustosunkowanie się do koncepcji lansowanych na łamach prasy zagranicznej.

Bazę źródłową niniejszego artykułu stanowią teksty zamieszczane na przełomie 1916 i 1917 r. w socjalistycznym "Naprzodzie”, liberalno-demo- 
kratycznej „Nowej Reformie”, konserwatywnym "Czasie” i czołowym (obok "Słowa Polskiego") prasowym przedstawicielu nurtu prozachodniego w Galicji jakim był katolicki "Głosu Narodu". Kwerenda objęła okres od dnia opublikowania noty Państw Centralnych do czasu pojawienia się ostatnich komentarzy na temat dokumentu wysłanego przez Koalicję. Należy przy tym zaznaczyć, że artykuły krakowskich dziennikarzy zawierały zazwyczaj wyłącznie ocenę działań Koalicji. Działań Rzeszy i jej sojuszników z zasady nie poddawano osądom bądź przekłamywano rzeczywistość na korzyść zaborcy. Nie może to dziwić $z$ racji ówczesnych uwarunkowań politycznych, w tym cenzuralnych. Prasa krakowska funkcjonowała w specyficznych warunkach trwającej wojny, której uczestnikiem były Austro-Wegry, co oczywiście nie mogło pozostać bez wpływu na treść zamieszczanych artykułów.

Pamiętając o kluczowej roli cenzury ustanowionej przez władze austro-węgierskie w 1869 r., wydaje się uzasadnione przybliżenie sytuacji krakowskich czasopism na przełomie XIX i XX w. Do 1914 r. dziennikarze wykorzystywali różne źródła informacji, m.in. czerpali z lepiej poinformowanych gazet zagranicznych, agencji Biura Korespondencyjnego w Wiedniu oraz jego filii we Lwowie i Krakowie. Zdarzało się również, że najświeższe wiadomości nadsyłali ze stolicy monarchii polscy posłowie parlamentarni. Jednak w ciężkich warunkach, ograniczone wspomnianą cenzurą (mowa tutaj o artykule 7 ustawy o stanie wyjątkowym z 5 maja 1869 r., który nakazywał poddanie cenzurze tekstu przed odbiciem nakładu; dodatkowo władze wojskowe wysyłały dyrekcjom policji informacje na temat tego, czego nie wolno umieszczać w prasie) i wpływem czynników wojskowych na kształtowanie informacji, w większości wypadków krakowskie redakcje publikowały komunikaty agencyjne, głównie wojskowe ${ }^{1}$. Nie oznacza to jednak, iż zabrakło artykułów opiniotwórczych. Te oddane do druku często świadczyły o dobrym przygotowaniu merytorycznym ich autorów, odznaczały się świetną stylistyką oraz oryginalnymi interpretacjami. Krakowscy dziennikarze oczywiście nie w pełni mogli wyrażać swój punkt widzenia, jednakże starali się to robić. Nierzadko pomagały im wiadomości i komentarze pojawiające się $\mathrm{w}$ prasie brytyjskiej i niemieckiej. W mniejszym stopniu eksploatowano za to publicystykę włoską (zajmowały się tym przede wszystkim "Głos Narodu" i "Nowa Reforma”).

Nie ulega wątpliwości, że decydenci zarówno Czwórprzymierza, jak i Czwórporozumienia, potraktowali notę z 12 grudnia 1916 r. jako kolejny etap gry dyplomatycznej rozpoczętej 28 lipca 1914 r. Trzeba też dodać,

1 J. Łojek et al., Dzieje prasy polskiej, Warszawa 1988, s. 77-80. 
że w politycznej rozgrywce brała udział liczna grupa podmiotów, które nie były bezpośrednio zaangażowane $\mathrm{w}$ zmagania wojenne, a więc też takich jak kraje neutralne (tutaj w roli głównej wystąpili Amerykanie) i Stolica Apostolska. Trudno wreszcie pominąć ważny czynnik w postaci oddziaływania opinii publicznej poszczególnych państw. Polaków te grudniowe zmagania dyplomatyczne interesowały głównie z powodu nadziei na rozwiązanie kwestii polskiej i faktu, iż linia frontu wschodniego przebiegała przez tereny dawnej Rzeczypospolitej.

Jak się wydaje, jednym z nielicznych polityków austro-węgierskich od dłuższego czasu zdających sobie sprawę z pogarszającej się sytuacji wielonarodowej monarchii był István Burián. Od 16 października 1916 r. zabiegał on - prowadząc rozmowy z czołowymi politykami niemieckimi o przedstawienie Entencie „umiarkowanych” i równocześnie możliwych do przyjęcia warunków pokoju. Kontekst wyznaczało tu pogarszające się położenie Państw Centralnych, odczuwających w coraz większym stopniu skutki blokady kontynentalnej i zmniejszających się zasobów. Powrót Rzeszy do negocjacji $\mathrm{z}$ Austro-Węgrami wiązał się przy tym $\mathrm{z}$ zatajoną wówczas strategiczną porażką, bowiem od mniej więcej lata 1916 r. dyskretnie oferując kosztem Imperium Osmańskiego ustępstwa terytorialne, w Berlinie błędnie liczono na odrębny pokój z Cesarstwem Rosyjskim² ${ }^{2}$.

Rozmowy na temat wspólnych warunków pokojowych rozpoczęły się 15 listopada w stolicy Niemiec. 6 grudnia wojska Państw Centralnych zdobyły Bukareszt, zaś dzień później politycy ukończyli redakcję noty. W tych okolicznościach ówczesny Szef Sztabu Generalnego Rzeszy Niemieckiej Paul von Hindenburg postanowił uprzedzić zapowiedzianą mediację pokojową prezydenta Stanów Zjednoczonych Woodrowa Wilsona. 12 grudnia dokument został przekazany przedstawicielom krajów neutralnych i Nuncjuszowi Apostolskiemu w Austro-Wegrzech, którzy w dalszej kolejności doręczyli go rządom Ententy i Ojcu Świętemu Benedyktowi XV 3 .

Treść noty zdominował niemiecki punkt widzenia, zawierała ona ogólniki bez żadnych konkretnych postulatów (szczegółowe propozycje pojawiły się w odrzuconym wariancie Buriána). Wybitny polski historyk Janusz Pajewski słusznie zauważył, że decydenci Czwórprzymierza zaadresowali ofertę w głównej mierze do narodu niemieckiego. Nota miała bowiem podnieść morale i wzmocnić przekonanie o zwycięstwie. Znamienne, że możliwość re-

2 J. Pajewski, Pierwsza wojna światowa 1914-1918, Warszawa 2004, s. 412-413.

3 Ibidem, s. 416-419; P. Hart, I wojna światowa 1914-1918. Historia militarna, Poznań 2014, s. $299-300$. 
zygnacji z kontynuowania zmagań tłumaczono względami humanitarnymi. Zapewne niemieccy przywódcy liczyli na to, że ich krok wzmocni istniejące już tendencje pacyfistyczne w obrębie Koalicji. Gdy chodzi o warunki zakończenia wojny, to Pajewski upatrywał w nich zarysu ukrytego przyszłego programu pokoju - zwycięskiego na Wschodzie i kompromisowego na Zachodzie. Tak wyrażone cele dyktowała sytuacja wojenna, wszak Rosja dysponowała mniejszymi rezerwami niż Wielka Brytania i Francja. Ukryta koncepcja pokoju równała się zachowaniu status quo na zachodzie (zmiany nie ominęłyby tylko Belgii), odzyskaniu bądź nawet powiększeniu kolonii, zdobyciu kontroli nad Królestwem Polskim, ścisłemu powiązaniu krajów bałtyckich z Rzeszą oraz ekspansji gospodarczej i politycznej w Rosji. Wyrażenie zgody na jej urzeczywistnienie - konstatował Pajewski - oznaczałoby oddanie zwycięstwa Czwórprzymierzu. W opinii historyka w nocie Państw Centralnych nie znalazło się ani jedno słowo, które choć w niewielkim stopniu mogłoby doprowadzić do rozpoczęcia negocjacji ${ }^{4}$.

Główne krakowskie czasopisma ów dobrze skalkulowany manewr Mocarstw Centralnych oceniły wszakże jako doniosły akt, potencjalnie istotny zwrot $\mathrm{w}$ dziejach trwającej wojny. Lwią część artykułów galicyjscy dziennikarze poświęcili próbom przewidzenia odpowiedzi Ententy oraz sprawie odpowiedzialności za rozpoczęcie światowego konfliktu. Niemal wszyscy, oprócz przedstawicieli „Głosu Narodu”, bardzo negatywnie przedstawiali obóz Koalicji; dochodząc nawet do wniosku, iż pokój można najszybciej osiągnąć poprzez doprowadzenie do rozpadu tego sojuszu. Pomijając ściśle związane $\mathrm{z}$ funkcjonowaniem na obszarze zaboru austriackiego krytyczne nastawienie poszczególnych redakcji, trzeba przyznać, że krakowscy obserwatorzy starali się przy tym wykorzystywać znajomość psychologii, by wpływać w określony sposób na nastawienie czytelników.

W ocenie żurnalistów socjalistycznego "Naprzodu” nota pokojowa, co prawda uboga $\mathrm{w}$ jakiekolwiek szczegółowe postulaty, zapewniała Mocarstwom Centralnym nietykalność terytorialną. W dalszej kolejności stwierdzano, iż Czwórporozumienie „nie kwapi się zasięgnąć języka co do warunków pokojowych”. Socjalistyczny dziennik starał się więc zasugerować, że gdyby Czwórporozumienie dążyło do podjęcia rokowań, wtedy samodzielnie wystosowałoby prośbę o rozmowy na temat takich postulatów. Lewicowi komentatorzy nie szczędzili słów krytyki pod adresem Koalicji - alians zbudowany od podstaw przez Zjednoczone Królestwo, Republikę Francuską

4 J. Pajewski, op. cit., s. 417-420. 
i Cesarstwo Rosji nazwali sojuszem „dobranym nieharmonijnie, sprzężonym wielokrotnie obietnicami, których nawzajem pogodzić nie można" 5 .

Chyba najmocniej sympatyzująca z Państwami Centralnymi „Nowa Reforma", redagowana przez pedagoga i działacza politycznego Michała Konopińskiego, od chwili pojawienia się noty budowała mit wielkodusznego i jakoby niepokonanego Czwórprzymierza. Rzekomo miało ono w chwili swojego największego triumfu ofiarować światu pokój. "Jako przedstawiciele wysokiej cywilizacji i najwyższego umoralnienia publicznego" - pisano - przywódcy potężnego aliansu wyprowadzili nowe uderzenie (rzecz o kapitulacji Rumunii) i pokazali, która ze stron rzeczywiście dąży do kontynuowania wojny, a która chce zawarcia pokoju. Grudniowa nota Państw Centralnych - błędnie przewidywali żurnaliści „Nowej Reformy” - w rocznikach ludzkości zapisze się jako „najwspanialszy dokument głębokiej mądrości i wysokiej moralności". Miała także błyskawicznie otworzyć drogę do rozpoczęcia rokowań, co jak wiadomo, nie nastąpiło ${ }^{6}$.

Analizując materiał prasowy nietrudno zauważyć, że działania decydentów Państw Centralnych, nawet te wątpliwe etycznie, były przedstawiane jako uzasadnione również przez dziennikarzy "Czasu". Jak pisano na łamach tego dziennika, "poważna i wysokim, humanitarnym duchem nacechowana nie jest ogólnikową deklaracją, którą można zbyć nic nie znaczącymi frazesami, ale ściśle określoną propozycją, która wymaga jasnej odpowiedzi". Kiedy wspaniałomyślni - jak sugerowano - politycy Państw Centralnych zaoferowali ludzkości ów "piękny zamiar” zamknięcia zmagań, bezwzględni przywódcy brytyjscy i francuscy postanowili rozpocząć, co prawda nieskuteczną, to jednak "obrażającą w najwyższym stopniu ludzkie uczucia" akcję wygłodzenia społeczeństw nieprzyjaciela. Apokaliptyczny obraz głodujących, chorych i umierających ludzi niewątpliwie miał wzmocnić tego rodzaju przekaz. Inne konkluzje publicystów "Czasu” tylko uwypuklały negatywne skojarzenia na temat Ententy. Sugerowano, że odrzucenie oferty oznaczać będzie wzięcie odpowiedzialności za wybuch wojny i jej dalszy przebieg. Konserwatywny dziennik szansy na zakończenie „bezcelowej walki" upatrywał w zmianach rządów w krajach Czwórporozumienia, sugerując, że narody powinny poszukiwać decydentów niewahających się położyć kres wojnie ${ }^{7}$.

5 Apel pokojowy z wtórem państw neutralnych, "Naprzód” 1916, nr 355, s. 1-2.

6 Nota Czwórprzymierza, "Nowa Reforma” 1916, nr 624, s. 1; (k.s.) [K. Srokowski], Wojenne przestanki pokoju, „Nowa Reforma” 1916, nr 636, s. 1.

7 O pokój, „Czas” 1916, nr 626, s. 1. 
Prawicowi żurnaliści z Krakowa nie ukrywali nadziei na rozpad Koalicji. Wskazywano, że interesy państw składających się na ten sojusz „nigdy nie były identyczne”, a do jego powstania doprowadziły "dwuznaczne obietnice obejmujące szereg wybitnych politycznych i gospodarczych przeciwieństw, przysłoniętych nadzieją wspólnych łupów”. „Teraz jednak kiedy perspektywa wygranej odsunęła się w mglistą dal" - konstatowali dziennikarze konserwatywnego dziennika - „sprzeczność interesów zaczyna rozsadzać początkową spójność”. Logicznie rozumując, „Czas” receptę na szybkie zakończenie zmagań widział w zaproponowaniu jednemu z państw tego „nienaturalnego związku" takich korzyści, które odwróciłyby dotychczas sojusznicze relacje we współzawodnictwo ${ }^{8}$.

Redakcja "Głosu Narodu” krok Rzeszy i jej sojuszników nazwała historycznym. Państwa Centralne osiągnęły wówczas apogeum sukcesów wojennych - klęska Rumunii ujawniła możliwości ofensywne, utrzymanie pozycji obronnych na froncie zachodnim umiejętności defensywne, i gdyby tylko to brać pod uwagę, intencje musiały być jak najbardziej szczere. W opinii katolickich dziennikarzy grudniowa oferta wywołała zmianę $\mathrm{w}$ dotychczasowym postrzeganiu Czwórprzymierza jako strony odpowiedzialnej za wybuch i dalsze trwanie wojny, i co mogło okazać się nie mniej istotne w kontekście niedalekiej przyszłości, tą metodą zdobyło przychylność krajów neutralnych. Ów ruch pozwolił jednocześnie Państwom Centralnym złagodzić napiętą sytuację wewnętrzną wywołaną wyczerpaniem własnych społeczeństw. Łącząc te wszystkie kwestie, redakcja "Głosu Narodu" wyraziła przekonanie, iż ze strategicznego i moralnego punktu widzenia ów „doniosły krok” był mistrzowskim posunięciem ${ }^{9}$.

Na łamach katolickiego dziennika wydawanego w dawnej stolicy Polski zastanawiano się też, czy Ententa udzieli jakiejkolwiek odpowiedzi, nie było to przecież koniecznością. Jeżeli Koalicja nie pominie milczeniem oferty Państw Centralnych - przewidywał "Głos Narodu" - to zgodnie ze zwyczajami dyplomatycznymi, do państw neutralnych, które wcześniej otrzymały dokument Czwórprzymierza, Ententa wyśle podpisaną przez kraje będące sygnatariuszami konwencji londyńskiej (odnosiło się to do Wielkiej Brytanii, Francji, Rosji, Włoch i Japonii) notę zbiorową. Ostatni fragment analizy traktował o treści, jaką mogła zawierać odpowiedź Czwórporozumienia. Było pewne, że nie pojawią się tam warunki pokojowe, bo i Państwa Centralne ich nie naświetliły. Prawdopodobnie - przypuszczali krakowscy komentato-

8 Ententa o pokoju, „Czas” 1916, nr 630, s. 1.

9 O początek układów, "Głos Narodu” 1916, nr 582, s. 5. 
rzy - Ententa odpowie, czy planuje przystąpienie do rokowań, nie mogła uczynić tego jednak natychmiast, ponieważ potrzebowała czasu na wypracowanie wspólnego stanowiska i przeprowadzenie umacniających jej pozycję operacji wojskowych ${ }^{10}$. Oprócz tego dziennikarze "Głosu Narodu" zalecali wskazanie postulatów, które pozwoliłyby Czwórporozumieniu na podjęcie rokowań. Tą metodą Ententa mogła wybronić się przed pułapkami tkwiącymi w nocie Czwórprzymierza, bowiem ów warunek Rzesza i jej sojusznicy prawdopodobnie by odrzucili ${ }^{11}$.

Nawet pobieżna kwerenda źródłowa przekonuje, że na łamach galicyjskich periodyków z przełomu 1916 i 1917 r. często przywoływano opinie i informacje pochodzące $z$ prasy zagranicznej. Polscy komentatorzy obficie korzystali z czasopism angielskich, włoskich i niemieckich, w wyraźnie mniejszym stopniu zaś z francuskich i rosyjskich, co skądinąd nie dziwi. Niewątpliwie nie pozostało to też bez wpływu na ogląd sytuacji wojennej prezentowany przez galicyjskich dziennikarzy.

Na podstawie lektury krakowskich dzienników z omawianego okresu można było się dowiedzieć, że świeżo mianowany na stanowisko premiera Wielkiej Brytanii Lloyd George zagwarantował na forum Izby Gmin, że odpowiedź na przedstawioną ofertę skonsultuje z sojusznikami. Miał on też przestrzegać polityków i opinię publiczną przed zbytnim pokładaniem wiary w obietnice wojskowych przywódców Rzeszy. Jak stwierdzano na łamach "Czasu”, szczególnie widoczne było, że wywodzący się z Partii Liberalnej premier Wielkiej Brytanii w swojej mowie wzbrania się przed krytyką całego bloku Czwórprzymierza, z jego perspektywy do wybuchu wojny przyczyniła się wyłącznie pruska generalicja ${ }^{12}$. Ówczesny minister bez teki Arthur Henderson nalegał z kolei, by Niemcy zapłaciły Entencie i zniszczonym przez wojnę Belgii i Polsce odszkodowania adekwatne do strat. Domagał się także zagwarantowania ochrony małych narodów przed atakami agresywnych mocarstw ${ }^{13}$. W „Nowej Reformie” informowano, że umiarkowani angielscy liberałowie uważali, iż autorom noty pokojowej zależało głównie na pozyskaniu przychylności krajów neutralnych i złagodzeniu napięć społecznych. Liberałowie zarazem nie ukrywali rozczarowania $\mathrm{z}$ powodu prawdopodobnego odrzucenia noty Rzeszy bez głębszego umotywowania. W ich

\footnotetext{
10 Zagadka Dumy, "Głos Narodu” 1916, nr 586, s. 5.

11 Po nocie pokojowej, "Głos Narodu” 1916, nr 585, s. 1.

12 Lloyd George o propozycji pokoju, "Czas” 1916, nr 637, s. 1.

13 Anglia przeciw pokojowi, "Czas” 1916, nr 625, s. 1; Zwrot w opinii angielskiej, „Nowa Reforma” 1916, nr 632, s. 3.
} 
refleksjach dokument stanowił „próbę wypośrodkowania drogi w kierunku negocjacji" 14 .

W prasie krakowskiej przytaczano $\mathrm{w}$ tym czasie komentarze m.in. redakcji „Daily Mail”. Sens zamieszczanych tam wywodów sprowadzał się do tezy, że Ententa nie może przyjąć oferty mocarstw centralnych, ponieważ „pokój z narodem tygrysów, rabusiów i mężów stanu, którzy wszelkie traktaty uważają za kawałek papieru, nie jest wart papieru ani atramentu". Z kolei "Morning Post", którego artykuły też były przytaczane, przedstawił propozycję Niemiec jako chytrą i rozpaczliwą próbę zmierzającą nie do zawarcia pokoju, lecz do tymczasowego zawieszenia broni dającego czas na odbudowanie armii. Redakcja „Timesa” pisała natomiast o popisie próżności i kłamstwach na temat potęgi Rzeszy, czy też geniuszu Paula von Hindenburga. Sama propozycja pokojowa miała w tym kontekście stanowić tylko i wyłącznie dowód słabości Niemiec i ich sojuszników ${ }^{15}$. Na łamach „Nowej Reformy" informowano, że w optyce londyńskiego tygodnika „Nation" angielski naród nie zastanawiał się jeszcze nad pokojem. Wyrażona została przy tym wątpliwość, czy w najbliższym czasie jedna ze stron znajdzie się w takim położeniu, które umożliwi jej podyktowanie warunków pokojowych ${ }^{16}$.

Prasa krakowska informowała, że inne angielskie czasopisma, jak choćby „Daily Chronicle”, „Star" i „Daily News" podpowiadały przedstawienie własnych postulatów pokojowych. Londyński „Star” wymienił tutaj oddanie Rosjanom Konstantynopola i cieśniny Dardanele, Francuzom Alzacji i Lotaryngii, opuszczenie okupowanych obszarów i zapłacenie odpowiednich odszkodowań. Redakcja "Daily News” przestrzegała z kolei polityków Ententy przed ugruntowaniem się opinii, że Niemcy proponują światu pokój, zaś Koalicja go ze wzgardą odrzuca. W ocenach tego dziennika Ententa była zobowiązana wystąpić $\mathrm{z}$ kontrofertą $\mathrm{w}$ postaci warunków pokojowych stosownych do poziomu niemieckich zbrodni, i to powinny być takie warunki, na jakie Rzesza nie wyrazi zgody. Rozumiano przez to m.in. rozbrojenie militaryzmu pruskiego oraz wydanie i zniszczenie artylerii i całej floty wojennej. W ten sposób Czwórporozumienie przesunęłoby odpowiedzialność za kontynuowanie zmagań na stronę przeciwnika. „Zwykłe odrzucenie propozycji Rzeszy" - konstatowali cytowani przez krakowskich dziennikarzy

\footnotetext{
14 Angielscy liberali za podjęciem rokowań, „Nowa Reforma” 1916, nr 631, s. 1.

15 "Times” o mowie pokojowej, „Nowa Reforma” 1916, nr 627, s. 2.

16 O pokój, „Nowa Reforma” 1916, nr 637, s. 1.
} 
żurnaliści „Daily News” - „okazałoby się największym jej zwycięstwem, a na to Koalicja nie powinna pozwolić" 17 .

W socjalistycznym "Naprzodzie” zwracano uwagę, że dziennikarze „Manchester Guardian” jako jedyni zajęli stanowisko pośrednie. Tylko oni powstrzymali się przed oznaczaniem negatywnymi epitetami noty Państw Centralnych i skłonni byli dopuścić myśl, że z uwagi na trudności gospodarcze intencje Rzeszy mogły okazać się szczere ${ }^{18}$.

W przeświadczeniu "Nowej Reformy” ten "straszliwy premier" i zarazem „wyznawca metody bokserskiej w polityce” Lloyd George w swojej wypełnionej „umiarem, porządkiem i powagą” przemowie okazał wielką bezradność wobec wyboru pomiędzy przedłużaniem wojny i wzięciem za nią odpowiedzialności a „wtykaniem głowy w wiszącą na sznurze pętlę propozycji niemieckich". Ta bezradność - wnioskował Konstanty Srokowski - wynikała z trudnego położenia strategicznego wyspiarskiego kraju. Owszem, Wielka Brytania jako jedyna spośród Ententy zachowała pozycję mocarstwa i potęgę morską, jednak „mogła już tylko tracić, nie zyskiwać”. Straty demograficzne i finansowe będą już tylko rosnąć, co gorsza, nikt nie zdoła zabezpieczyć monarchii brytyjskiej przed ewentualnością samotnej walki przeciwko największemu wrogowi - Niemcom, i w dłuższej perspektywie Londyn walkę tę przegra - konstatował ufny w triumf Rzeszy komentator liberalnego pisma z Krakowa ${ }^{19}$.

Czytelnicy gazet ukazujących się $\mathrm{w}$ dawnej stolicy Polski mogli się dowiedzieć, że politycy brytyjscy na czele z premierem, ale też „robiąca gwałtowne grymasy siły i pewności siebie” prasa na Wyspach zachowują niemal całkowitą jednomyślność w sprawie grudniowej oferty. Zdaniem "Nowej Reformy" ta okoliczność miała pomóc przy negocjowaniu lepszych warunków pokoju. Koalicja domagała się od Państw Centralnych ogłoszenia postulatów, dzięki którym mogłaby osiągnąć cele wojenne i ewentualnie usprawiedliwić swój manewr przez opinią publiczną; wówczas „,z wdzięcznością zakończyłaby [...] wysiłki" ${ }^{20}$. Komentatorzy "Czasu” podkreślali, że Wielka Brytania jest kontrolującą każdy krok sprzymierzeńców "główną sprężyną wojny" 21.

17 Nieszczera oferta, „Nowa Reforma” 1916, nr 627, s. 1; Stanowisko Anglii, „Czas” 1916, nr 627, s. 1.

18 Echa propozycji pokojowych, „Naprzód” 1916, nr 347, s. 1.

19 (k.s.) [K. Srokowski], Solo kwartet, „Nowa Reforma” 1916, nr 638, s. 1.

20 Idem, Pierwsze Głosy, "Nowa Reforma” 1916, nr 630, s. 1.

21 Koalicja a nota pokojowa, „Czas” 1916, nr 636, s. 1. 
Warto zaznaczyć, że żurnaliści "Głosu Narodu” z pewną dozą respektu oceniali na przełomie lat 1916/1917 „najbezwzględniejszego polityka angielskiego", Lloyd George'a. Brytyjskiego premiera - wskazywano - nie interesowały opinie wrogów, świadczyć o tym miała nacechowana „bokserskim” tonem mowa polityka. Katoliccy dziennikarze podejrzewali, iż przejęcie przez Niemcy inicjatywy na frontach wojennych i w dziedzinie polityki skłoni jednak Londyn do zmiany bezkompromisowej postawy 22 .

Wydaje się, że "słowa o brzmieniu donośnym i stanowczym" pojawiające się w komentarzach liderów Ententy oraz ataki na "chytrość i podstępność" uznano w kręgach dziennikarskich Krakowa za element konwenansu dyplomatycznego, w związku z czym podkreślano, aby nie przykładać do nich istotnej wagi. Owe sformułowania miały wywrzeć wrażenie siły i nieustępliwości, co mogło, chociaż raczej w niewielkim stopniu, wpłynąć na ewentualny przebieg rokowań. Krakowscy dziennikarze nie ukrywali zadowolenia z powodu braku głosów świadczących o bezwzględnym odrzuceniu oferty przez Koalicję. Kontynuując poprzednią analizę doszli do wniosku, iż brytyjskie żądania zadośćuczynienia przypuszczalnie stanowiły rodzaj przedwstępnego warunku, od którego Ententa uzależni przystąpienie do rokowań ${ }^{23}$.

Państwem, którego stanowisko wobec noty pokojowej z grudnia $1916 \mathrm{r}$. miało niezwykle istotne znaczenie, była oczywiście także Francja. W trakcie grudniowych posiedzeń Izby Deputowanych i Senatu nieufny co do niemieckich zapewnień o pokoju socjalistyczny premier tego kraju Aristide Briand notę Państw Centralnych przedstawił jako fortel. Snuł przypuszczenia, że przeżywająca trudne chwile Rzesza dąży do wzbudzenia wiary $\mathrm{w}$ to, jakoby rozpoczęcie działań zbrojnych na niej wymuszono. Ten planujący od ponad 40 lat wojnę kraj - zaznaczył z oburzeniem Briand - kreując się na zwycięzcę, oszukuje państwa neutralne i opinię publiczną, i niestety, czyni to skutecznie. Francuski polityk przestrzegał przed niebezpieczeństwem zawarcia odrębnego układu przez któregoś z aliantów, i tym samym niezachowaniem przez Koalicję jednomyślności. Uznawał za prawdopodobne wystąpienie antagonizmów pomiędzy władzami państw a społeczeństwami ${ }^{24}$.

22 Odwleczone wyjaśnienie, „Głos Narodu” 1916, nr 588, s. 1; Zagadka Dumy...

23 Ibidem.

24 Briand o propozycji pokoju, „Czas” 1916, nr 639, s. 1; Deklaracja rządu francuskiego, "Czas” 1916, nr 629, s. 1. 
Szczególną awersję w stosunku do premiera Francji żywili komentatorzy "Naprzodu”. W ich ocenie słowa nieprzejednania z ust Lloyd George’a brzmiały inaczej niż te wypowiedziane przez Brianda. Zdaniem redaktorów socjalistycznego dziennika Brytyjczyków poniekąd chroniło wyjątkowe, blokujące możliwości ofensywne Czwórprzymierza, położenie geograficzne. Francja zaś znajdowała się w zupełnie innej sytuacji. Jak pisano, „opętana jakąś manią", wydawała się niepoważna, bo jej rezerwy demograficzne i gospodarcze znalazły się już pod koniec 1916 r. na skraju wyczerpania: „jej terytoria doznały okupacji nieprzyjacielskiej, jej krwawienie się o przełamanie frontu niemieckiego powiększa tylko na jej niekorzyść dysproporcję w materiale ludzkim, osłabia ją w punkcie jej najsłabszym, stopniowego wygubiania niesłychanie przerzedzonej ludności męskiej”. Socjalistów z redakcji „Naprzodu” dziwiła niechęć władz w Paryżu do rokowań, tym bardziej, że Niemcy nie brały pod uwagę aneksji francuskich ziem. Krakowscy dziennikarze spointowali całą analizę sugestią, że należy sobie życzyć, by „instynkt samozachowawczy narodu francuskiego wziął w końcu górę nad tragicznym dlań oratorstwem różnych Briand'ów" 25.

W opiniach dziennikarzy „Nowej Reformy” słowa Brianda o dalszej wojnie brzmiały prowokacyjnie, jednak wyraźnie łagodniej niż exposé Nikołaja Pokrowskiego, szefa rosyjskiej dyplomacji. Francja znalazła się w takim samym położeniu co Rosja - nie osiągnęła przecież celów wojennych i pogrzebała „przyszłość gospodarczą". Pocieszenie stanowiło prawdopodobne utrzymanie aktualnych granic, co w przypadku państwa cara należałoby wykluczyć26. Redaktorzy "Nowej Reformy” wyrażali przy tym zaskoczenie niezachwianą wiarą francuskich przywódców w zwycięstwo. Jak sądzono, brakowało jakichkolwiek przesłanek politycznych i gospodarczych przemawiających za tą graniczącą z arogancją pewnością siebie. Nieprzejednane stanowisko francuskiego premiera - oceniał Srokowski - miało swoje źródło w niemożności zachowania przez Koalicję jednomyślności w kwestii pokoju, różnice były zaś tak wielkie, iż nazajutrz po zawarciu pokoju kraje Ententy wywołałyby wojnę pomiędzy sobą. Wolały tego uniknąć, tak więc nie pozostało im nic innego, jak walka z Państwami Centralnymi ${ }^{27}$.

Francuski premier był krytykowany także przez redaktorów "Czasu". Nie wzniósł się, tak jak rzekomo powinien, do „wyższej oceny tak doniosłego i poważnego aktu”, zdołał zaledwie dostrzec w nim polityczną intrygę.

25 Po słowach Brianda, „Naprzód” 1916, nr 351, s 1.

26 (k.s.) [K. Srokowski], Solo kwartet...

27 (k.s.) [K. Srokowski], Druga mowa Brianda, „Nowa Reforma” 1916, nr 640, s. 1. 
Propozycja Państw Centralnych ujawniła i wzmocniła tęsknotę społeczeństw Koalicji za pokojem. Prawicowi dziennikarze zarzucili Briandowi także brak wrażliwości na problemy narodu - „oficjalnie widzi tylko zewnętrzną grozę wojennej sytuacji; narody sądzą ją według ilości krwi przelanej, według ofiar już poniesionych”. Ta „zasadnicza różnica zapatrywań" nie mogła długo przetrwać, szczególnie we Francji, gdzie „ustrój republikański dąży do jak najściślejszego związku pomiędzy rządem a społeczeństwem" - m.in. to stąd miał pochodzić nerwowy ton wypowiedzi polityka ${ }^{28}$.

Jak była już o tym mowa, istotnym punktem odniesienia dla krakowskich dziennikarzy było też, wygłoszone w obecności zaledwie nieco ponad połowy deputowanych do Dumy Państwowej i przy absencji premiera Aleksandra Trepowa, wystąpienie Pokrowskiego ${ }^{29}$. Szef dyplomacji Imperium Rosyjskiego, odnosząc się do inicjatywy Czwórprzymierza, zwrócił uwagę na stały element strategii Państw Centralnych. Sugerował, że każdorazowo po rozdmuchanym propagandowo zwycięstwie Rzesza i jej sojusznicy, wykorzystując opinie publiczne państw neutralnych, proponowały odrębny pokój jednemu z krajów Ententy. Pokrowski wyraził obawy co do wiarygodności pokojowych planów Niemiec, trafnie oceniając, że grudniowa oferta służy wyłącznie wzmocnieniu podupadającego ducha narodu niemieckiego. Przy pełnej aprobacie, będącej wszakże w okrojonym składzie Dumy, obiecał realizację celów wymienionych w planach wojennych i zniszczenie wroga. Zgoda na „obłudną" propozycję pokoju - sugerował rosyjski minister - pozwoliłaby Niemcom na przeniesienie odpowiedzialności za wybuch wojny na Ententę i zdobycie w niedalekiej przyszłości hegemonii w Europie, czego rosyjscy politycy nie mogli zaakceptować. Ów pokój pojmował jako tymczasowe zawieszenie broni, które przyniosłoby krótkotrwałą przerwę w zmaganiach ${ }^{30}$.

28 Ententa o pokoju... Nie można wykluczyć, iż nerwowa postawa francuskiego polityka wiązała się z pogłoskami o planach Senatu dotyczącymi jego zdymisjonowania. W tym samym czasie w Izbie Deputowanych wzrosła liczebność działaczy opozycyjnych, natomiast ugrupowaniu socjalistów, z którego wywodził się Briand, groził rozpad. Por.: Koalicja a nota...

Żurnaliści „Naprzodu” zastrzeżenia żywili co do składu Dumy Państwowej. Nie mieli wątpliwości, iż gdyby władze zaczekały z przedstawieniem stanowiska jeszcze kilka dni, parlament nie zaaprobowałby przemowy Pokrowskiego - Echa propozycji pokojowych.... Warto dodać, że niektóre z rosyjskich ugrupowań apelowały o zapoznanie się ze szczegółowymi warunkami pokoju. Takie odrzucenie z góry - przekonywano - mogłoby wywrzeć złe wrażenie wśród chłopów, armii i robotników, co spowodowałby lawinę kłopotów aprowizacyjnych i logistycznych.

30 Po propozycji pokojowej, „Czas” 1916, nr 637, s. 3; Rosja przeciw pokojowi, „Czas” 1916, nr 631, s. 1; Rosja przeciw pokojowi, "Czas” 1916, nr 633, s. 1; Rosyjska Rada Państwowa przeciw pokojowi, „Czas” 1916, nr 637, s. 1; Rzą i parlament w Rosji, „Czas” 1916, nr 634, s. 1; Uchwała dumy, "Czas” 1916, nr 633, s. 1. 
Na łamach „Nowej Reformy” oceniano w tym czasie, że car przyjął postawę "absolutnie wojowniczą i zdecydowanie nieprzejednaną". Budziło to zdumienie komentatora dziennika, który podkreślał, że Rosja poniosła dotąd największe straty w wojnie. Jak pisał Srokowski, Imperium skutecznie szantażowało Koalicję groźbą odrębnego pokoju, Wielka Brytania zaś nie chcąc do tego dopuścić "dawała pieniądze i płaciła fabrykantom amerykańskim zaległe rosyjskie rachunki". Przekonanie, iż car nie wyrazi zgody na rozpoczęcie rokowań, miało więc według komentatorów krakowskiego dziennika związek z aspektem finansowym. Wiązało się też jednak z niezaspokojonymi aspiracjami terytorialnymi Rosji. Car, wskazywano, nie osiągnął żadnego ze swoich celów. Utracił Polskę, Kurlandię, Litwę i część Wołynia, a jego prestiż na Bałkanach wyraźnie podupadł. Łączyć się miały z tym obawy związane z ewentualnym wypłaceniem większej części odszkodowań na rzecz Państw Centralnych ${ }^{31}$.

Komentatorzy "Czasu” z kolei doszli do przekonania, że przemowy szefa dyplomacji i aprobaty ze strony okrojonego parlamentu, nie należy „tłumaczyć zbyt tragicznie". Duma w tamtym okresie poprzez przedłużanie wojny dążyła do dalszej reformy ustroju w kierunku parlamentarnym i do rozrachunku z biurokratycznymi rządami. Uściślając - różne ugrupowania wykorzystywały wojnę $\mathrm{w}$ dowolny sposób dla realizacji własnych celów. Co więcej, jak zaakcentowali prawicowi żurnaliści, w Rosji w rzeczywistości brakowało prawdziwej partii wojennej. Tak więc, i bez nacisków Anglii, myśl o zawarciu pokoju pojawiłaby się tam o wiele wcześniej aniżeli w innych krajach Ententy ${ }^{32}$.

Krakowskie dzienniki przywoływały też opinie czołowych polityków włoskich. Informowano, że szef dyplomacji Królestwa Włoch Giorgio Sidney Sonnino w przemowie na forum Izby Poselskiej wyraził przekonanie, iż gdyby Państwa Centralne przedstawiły konkretne postulaty, Koalicja nie powinna odrzucać z góry tej inicjatywy. Problem miał polegać jednak na tym, że tych postulatów nikt nie przedstawił, co zaznaczał polityk. Tak samo jak Briand, Sonnino ostrzegał przed zawarciem odrębnego zawieszenia broni z nieprzyjacielem. Sam manewr Niemiec ocenił jako podstępny, a notę jako nieszczerą. Nie zapomniał również wezwać włoskich decydentów do powstrzymania się przed komentarzami sugerującymi możliwość zajęcia przez Italię odmiennego stanowiska niż sojusznicy ${ }^{33}$.

31 (k.s.) [K. Srokowski], Solo kwartet...

32 Koalicja a nota pokojowa...

33 Echa propozycji pokojowych „Naprzód” 1916, nr 349, s. 3; Mowa Sonnino w Izbie Włoskiej, „Nowa Reforma” 1916, nr 636, s. 3. 
Z prasy codziennej wychodzącej w Krakowie można było się dowiedzieć, że podobnie sprawę skomentowały m.in. włoskie Rady Miast ${ }^{34}$, zdecydowana większość tamtejszych ugrupowań politycznych, premier Paolo Boselli, redakcje pism takich jak "Avanti” i "Stampa"35. „Corriere d'Italia" dodatkowo wystosował apel, aby nie rezygnować z przygotowywania się do dalszych zmagań $^{36}$. Z kolei mniej ufni $\mathrm{w}$ zapewnienia decydentów Czwórprzymierza obserwatorzy „Il Secolo" i „Il Messaggero" konstatowali, że za propozycją pokojową stał brak wiary $\mathrm{w}$ odniesienie rozstrzygającego zwycięstwa ${ }^{37}$. Nieukrywająca niechęci do Austro-Węgier redakcja katolickiego dziennika „Italia” dodawała, że Czwórprzymierze w „niesmaczny i arogancki sposób podkreślało swoją niepokonalność, choć w rzeczywistości stało u kresu swoich sił" ${ }^{38}$. Najbardziej nieugiętą z gazet włoskich wobec niemieckiej propozycji okazała się wydawana przez popierającego wojnę $\mathrm{u}$ boku Czwórporozumienia Benito Mussoliniego „Il Popolo d'Italia”. To na jej łamach przyszły faszystowski dyktator propagował hasło „wojna aż do zwycięstwa!" 39 .

W ocenie obserwatorów „Nowej Reformy” mowa Sonnino odzwierciedlała stanowisko całych Włoch, co jednak nie do końca było prawdą. Do wydania oświadczenia pełnego „umiaru, porządku i powagi” miał przyczynić się strach przed zagrożeniem ze strony Państw Centralnych. Włoscy politycy przewidywali, że po Rumunii Czwórprzymierze zaatakuje nowego najsłabszego członka Koalicji - ich ojczyznę. Srokowskiemu wydawało się logiczne, że $w$ takiej sytuacji najwyższym pragnieniem Królestwa Włoch powinno być wycofanie się z walk, bez narażania się na niepotrzebne zniszczenia i koszty finansowe ${ }^{40}$. Do tak krytycznych wniosków prowadziły liczne przesłanki. Za przykład mogły posłużyć chociażby silnie antywojenny i antyangielski nastrój, głęboki kryzys gospodarczy oraz liczne skandale z udziałem wojskowych i polityków ${ }^{41}$.

\footnotetext{
34 Miasta włoskie za pokojem, Nowa Reforma” 1916, nr 633, s. 1.

35 Głosy włoskie za pokojem, „Nowa Reforma” 1916, nr 630, s. 1.

36 Głosy włoskie za pokojem, "Nowa Reforma” 1916, nr 632, s. 1.

37 Rezerwa prasy włoskiej, Nowa Reforma 1916, nr 628, s. 1.

38 Głosy prasy włoskiej, „Nowa Reforma” 1916, nr 628, s. 3.

39 Oświadczenie rząu włoskiego, "Czas” 1916, nr 629, s. 1; Parlament włoski o pokoju, „Czas” 1916, nr 635, s. 1; Sonnino o propozycji pokoju, "Czas” 1916, nr 637, s. 1; „Wojna aż do zwycięstwa”, "Czas" 1916, nr 627, s. 1.

40 (k.s.) [K. Srokowski], Solo kwartet...

41 Pierwsze głosy...
} 
Tak jak inne krakowskie periodyki, „Czas” przyznawał, że wystąpienie Sonnino wyróżniało się wstrzemięźliwością, odmowa zaś nie była bezwarunkowa. Konserwatywni dziennikarze z Galicji wątpili w możliwość utrzymania jednolitości przez Ententę, albowiem w hipotetycznym scenariuszu, którego nikt całkowicie nie wykluczył, postulaty pokoju mogły okazać się korzystne dla niektórych krajów Koalicji. Redakcja "Czasu” przypuszczała, że gdyby włoscy decydenci stanęli przed takim wyborem, zapomnieliby o wspólnych celach wojennych ${ }^{42}$.

Należy dodać, że prezydent Stanów Zjednoczonych Ameryki Woodrow Wilson odmówił zajęcia stanowiska wobec propozycji Państw Centralnych. Obojętna postawa kojarzonego dotąd z propagowaniem inicjatyw pokojowych polityka łączyła się z planem wprowadzenia w życie jego własnego pomysłu mediacji ${ }^{4}$. Jak obszernie pisano na łamach "Czasu", Wilson tuż przed Świętami Bożego Narodzenia zaproponował wymianę dokumentów z uwzględnieniem szczegółowych warunków pokojowych przez obydwie walczące strony, a w dalszej perspektywie sugerował zwołanie konferencji na terytorium państwa neutralnego ${ }^{44}$. W tym samym dzienniku można było przeczytać, że do końca 1916 r. propozycje pośrednictwa w negocjacjach wysunęły także Szwecja, Norwegia i Dania oraz postrzegana przez Ententę jako znajdująca się pod silnym wpływem Niemiec Szwajcaria ${ }^{45}$.

W przekonaniu dziennikarza "Nowej Reformy” amerykański prezydent gruntownie przeanalizował, jaki oddźwięk może przynieść nota Czwórprzymierza. Kiedy uznał, że niewielki, postanowił porzucić dotychczasową bierność. Efekty jego działań wpłynęły na opóźnienie ustalenia jednolitej odpowiedzi przez Ententę. Przedłużający się okres oczekiwania na reakcję Koalicji pozwolił Srokowskiemu wywnioskować, że interwencja Wilsona, ale też władz Szwajcarii, wpłynęły znacząco na treść tekstu. Z kolei błyskawiczna i pozytywna odpowiedź Rzeszy i Austro-Węgier na amerykańską propozycję miała tylko potwierdzić szczerość pokojowych zapewnień Państw Centralnych ${ }^{46}$.

Nota Wilsona wiele zmieniła w opiniach krakowskich dziennikarzy. Pomimo nieprzychylnej reakcji Ententy, pozwoliła zachować wiarę w podjęcie

\footnotetext{
42 Ententa o pokoju...; Koalicja a nota...

43 A. Chwalba, Samobójstwo Europy. Wielka wojna 1914-1918, Kraków 2014, s. 282-285.

44 Nota Wilsona do prowadzących wojnę, "Czas” 1916, nr 643, s. 1; O przywrócenie pokoju, "Czas" 1916, nr 645, s. 1; Stany Zjednoczone a propozycja wojny, „Czas” 1916, nr 631, s. 1.

45 Akcja pokojowa Danii, Norwegii i Szwecji, „Czas” 1917, nr 1, s. 1; O pokój, „Czas” 1916, nr 650, s. 3.

46 (k.s.) [K. Srokowski], Interwencja neutralnych, „Nowa Reforma” nr 646, s. 1.
} 
negocjacji pomiędzy zwaśnionymi stronami. Można domniemywać, że gdyby Wilson zaniechał interwencji, opinie na temat Czwórporozumienia wyrażane $\mathrm{w}$ krakowskich dziennikach okazałyby się o wiele bardziej nieprzyjazne. Komentatorzy apelowali, by powstrzymać się z ostatecznymi wnioskami do momentu, kiedy Koalicja zareaguje na inicjatywy krajów neutralnych, bo wówczas nie będzie mogła bronić się „ogólnikami i frazesami”, jak działo się to w przypadku ujawnienia swojego stanowiska wobec oferty Państw Centralnych.

Dalszy bieg wydarzeń w oczywisty sposób wpływał na ton komentarzy. 30 grudnia 1916 r. francuski dyplomata Jules Cambon wręczył szwajcarskiemu posłowi w Paryżu odpowiedź Koalicji, w której ta podważyła wszystkie spostrzeżenia Czwórprzymierza. „Nieszczera i pozbawiona znaczenia” propozycja pokojowa miała okazać się niczym innym jak manewrem wojennym obliczonym na pozyskanie krajów neutralnych, podtrzymanie motywacji do dalszych walk w narodach Państw Centralnych oraz skłócenie opinii publicznej Ententy. W toczącym się sporze o odpowiedzialność za wybuch tego konfliktu zbrojnego Koalicja przeciwstawiła się oskarżeniom Czwórprzymierza, odrzuciła zarzut o jej wywołanie. Zasugerowano zarazem, że aktualnie niekorzystna europejska "mapa wojenna” nie odzwierciedla rzeczywistego stosunku sił i przystąpienie w tym momencie do negocjacji kończących konflikt przyniosłoby korzyści wyłącznie oponentowi. Tak samo jak Czwórprzymierze, Ententa nie sprecyzowała szczegółowych warunków pokojowych, wymieniła wyłącznie te uogólnione, jak na przykład żądanie odszkodowań za zniszczenia dokonane przez Rzeszę i jej sprzymierzeńców ${ }^{47}$.

W zapatrywaniach „Nowej Reformy” blisko dwudziestodniowy okres zwlekania z odpowiedzią i ubóstwo jej treści pokazały poziom trudności, jaki kraje Czwórporozumienia przezwyciężyły, zanim osiągnęły jednolite stanowisko. Tylko w kilku kwestiach wykazały całkowitą zgodność: Ententa wojny nie wywołała, nie uznała siebie za zwyciężoną i dążyła do odtworzenia Belgii. Pierwszy z wymienionych punktów, "nieistotny” zdaniem żurnalistów, „świadczył bardziej o uporze niż przenikliwości autorów”. Postulat belgijski stanowił stały punkt wypowiedzi władz Koalicji, które o pozostałych państwach wspominały niewiele, bo zaledwie to, że należą się im sankcje, gwarancje i reparacje. Tej „pełnej opryskliwości” odpowiedzi obserwatorzy „Nowej Reformy” nie uznali jednak za „nieubłagalnie odmowną” - „przed pokojem Koalicja przymknęła drzwi, ale ich nie zatrzasnęła" 48 .

47 Odpowiedź koalicji, „Czas” 1917, nr 1, s. 1.

48 (k.s.) [K. Srokowski], Odpowiedź koalicji, „Nowa Reforma” 1917, nr 3, s. 1. 
Z kolei redaktorzy "Czasu” notę zbiorową Ententy ocenili jako dyplomatyczny wykręt, który „nie przecina możliwości dalszej wymiany zdań na temat pokoju". Było oczywiste, że Koalicja przeniesie odpowiedzialność za rozpoczęcie zmagań na Państwa Centralne. Unikała ścisłego określenia celów wojennych, powtarzała ogólniki, z których „nie płynęły żadne zobowiązania", żądała sankcji, gwarancji i zadośćuczynienia, nie wskazała jednak, na czym powinny one polegać. $Z$ punktu widzenia krakowskich komentatorów głównym celem Czwórporozumienia było wyjaśnienie społeczeństwu, dlaczego wojnę przedłuża, a propozycję pokoju odrzuca. Absurdalna wydawała się przy tym niechęć zaakceptowania jeszcze stosunkowo korzystnej „europejskiej mapy wojennej” i bazowanie na „mapie afrykańskiej”, która nie mogła wpłynąć decydująco na wynik wojny ${ }^{49}$.

Dziennikarze "Głosu Narodu" stanęli na stanowisku przeciwnym. W ich refleksji Ententa określiła warunki rokowań: „pokój nie jest możliwy, póki nie mają gwarancji, co do przywrócenia praw i swobód, co do uznania zasadniczych praw narodowościowych i wolnego istnienia małych państw, póki nie są pewne takie uregulowania spraw, które by było zdolne usunąć przyczyny zagrażające ludziom od dawna - i dać światu jedynie skuteczne gwarancje bezpieczeństwa". Nota koalicji w przeświadczeniu redakcji katolickiego dziennika nie mogła być uważana za odmowną, mimo że Ententa odrzuciła "zajmowanie się propozycją nieszczerą i pozbawioną znaczenia". Sprawą, która mogłaby przybliżyć rokowania pokojowe, był w tym ujęciu postulat przywrócenia niepodległości Belgii. "Głos Narodu" proponował Wilsonowi rozszerzenie fundamentów swojej koncepcji i wystosowanie do Czwórporozumienia oferty rozmów. Jak sądzono, jeżeli Ententa, tak samo jak Państwa Centralne, pozytywnie odpowie na notę amerykańskiego prezydenta, to zaproponuje $\mathrm{w}$ niej raczej wymianę postulatów przedwstępnych. Należało się również spodziewać, że Koalicja zechce poprawić swoją sytuację na „wojennej mapie Europy”, dlatego do rokowań najwcześniej przystąpi po nowej ofensywie wiosennej. Wywody etyczno-polityczne władz Czwórporozumienia nie były istotne z punktu widzenia społeczności międzynarodowej. Ententa przeniosła odpowiedzialność za rozpoczęcie wojny i dalsze jej trwanie na Państwa Centralne w celu oddalenia konfliktów wewnętrznych, które mogły wybuchnąć z powodu odrzucenia noty pokojowej. Za ,jądro" odpowiedzi katoliccy żurnaliści uznali wysunięcie warunków przedwstępnych ${ }^{50}$.

\footnotetext{
49 Odpowiedź koalicji, "Czas” 1917, nr 2, s. 1.

50 Jądro i Łupina, „Głos Narodu” 1917, nr 2, s. 1.
} 
Nie ma wątpliwości, że cztery najważniejsze krakowskie dzienniki opiniotwórcze okresu Wielkiej Wojny z dużym respektem pisały na temat posunięć Wielkiej Brytanii, postrzeganej jako filar Ententy. Włochy traktowano zaś jako kraj, który nakłaniany różnymi korzyściami przez Państwa Centralne mógłby zburzyć jednolitość Koalicji, dlatego niezależnie od orientacji periodyku niemal wszystkie opinie włoskich polityków i periodyków były oceniane pozytywnie. Na przeciwległym biegunie znalazły się Francja i Rosja. Podkreślano, że władze tych państw, pomimo trudnej sytuacji militarnej i gospodarczej (w przypadku III Republiki dochodziły jeszcze problemy demograficzne), zdecydowanie najgłośniej nawoływały do kontynuowania walk (tutaj nie można jednak całkowicie zaakceptować wniosków polskich komentatorów).

Ogłoszenie grudniowej noty splotło się ze zmianą rządów w Londynie. Krakowscy komentatorzy krótko przeanalizowali dotychczasową biografię i działalność polityczną postrzeganego jako lidera Czwórporozumienia Lloyd George'a. Dość zgodnie uznawano, że to jego głos okaże się rozstrzygający przy ustaleniu treści odpowiedzi na notę. Jednakże i tutaj obserwatorzy chybili w analizach. Decydująca okazała się propozycja mediacji ze strony prezydenta Wilsona, która nie tylko opóźniła odpowiedź, ale i zmieniła jej optykę. Można przy tym dodać, że działania prezydenta USA nie wpłynęły raczej znacząco na istotną treść dokumentu, ale gdyby nie jego interwencja, krakowskie periodyki postrzegałyby reakcję Koalicji na notę grudniową o wiele bardziej negatywnie.

Analizując teksty prasowe z przełomu 1916 i 1917 r. nietrudno dostrzec, że dziennikarze zwłaszcza "Naprzodu”, „Nowej Reformy” i „Czasu” nieraz tworzyli hipotetyczne scenariusze, w których szkicowano drogę do podjęcia rozmów kończących zmagania. Zazwyczaj, co rzecz jasna nie dziwi, sugerowana była możliwość zawarcia przez Państwa Centralne odrębnego pokoju z jednym z członków Ententy. W konsekwencji oznaczałoby to prawdopodobny rozpad tego sojuszu i bliską już perspektywę zakończenia wojny.

\section{Bibliografia}

\section{Źródła}

„Czas" 1916-1917

„Głos Narodu” 1916-1917

„Naprzód” 1916-1917

„Nowa Reforma” 1916-1917 


\title{
Opracowania
}

Chwalba A., Samobójstwo Europy. Wielka wojna 1914-1918, Kraków 2014.

Hart P., I wojna światowa 1914-1918. Historia militarna, Poznań 2014.

Łojek J. et al., Dzieje prasy polskiej, Warszawa 1988.

Pajewski J., Pierwsza wojna światowa 1914-1918, Warszawa 2004.

\section{Opinions on the peace note of the Central Powers from December 1916 and the ensuing response of the Entente in contemporary Krakow press}

\begin{abstract}
Summary
The article centers upon the opinions printed in leading Krakow daily newspapers regarding the peace note of the Central Powers from 12 December 1916 and the consecutive response of the Quadruple Alliance. My research provided an opportunity to explore several important themes, such as the varying opinions on the Entente's actions, the subject of blame for starting and prolongation of the Great War, and reactions to notions disseminated by the foreign press.

The primary sources used in the research comprise articles published in years 1916 and 1917 in socialist "Naprzód", liberal-democratic "Nowa Reforma", conservative "Czas" and pro-Western, Catholic "Głos Narodu" daily newspapers. These articles were usually only concerned with evaluating the Entente's course of action, avoiding making judgments on the policy of Germany and her allies. This was dictated by the contemporary political climate and censorship.
\end{abstract}

Norbert Szklarzewski - mgr stosunków międzynarodowych, absolwent Uniwersytetu w Białymstoku

e-mail: nor.szklarz.1990@gmail.com 